\title{
Mother Factory Worker's Parenting Style and its Implication for Early Childhood Islamic Education*
}

\author{
Enoh, Erhamwilda, Nurul Afrianti \\ Education Faculty \\ Universitas Islam Bandung (Unisba) \\ Bandung, Indonesia \\ noh_roni@yahoo.com, erhamhoernis@gmail.com,nurulafrianti28@gmail.com
}

\begin{abstract}
Currently, the mother who works in the factory has increased from year to year caused by various factors. This condition triggered a debate related to its influence on the development of children, especially education in early childhood. To explore this problem, this research is aimed to know the mother's parenting style that works in the factory and its implication to early childhood Islamic education. This research use case study method. Instruments used to collect data are Parenting Style and Dimensions Questionnaire (PSDQ) and in-depth interviews.
\end{abstract}

Keywords—-parenting style, early childhood education, factory worker's, Islamic education

\section{INTRODUCTION}

In Islam, Mother is a madrasah for children. This means that a mother is not only a woman who gives birth and raises a child, but she is also required to be able to guide and educate her children to be a respectful person to parents, family, community, and religion. Preparing for a devoted generation is not easy. A mother needs to have adequate knowledge and skills in developing the potential of the child. At the same time, over the course of time, the mother's role has undergone a shift which, among other things, becomes an extra breadwinner for her family.

In recent, the number of female workers has continued to increase from year to year. Data from West Java BPS (Anshari, 2015) [1] indicates that 2014 working mothers were 4,855,268 million $(75.06 \%)$ and in 2015 increased by 5,819,859 million $(81.25 \%)$. Based on this data, it can be ascertained that mothers who work especially outdoors, then the activity at home to be reduced. When the activity at home is reduced, then the time to care, nurture and guide the child is also reduced. This condition certainly needs to be anticipated so that mother care for children is not hampered due to work problems.

The results of studies in some cases abroad about working mothers, it turns out the impact is quite astonishing. For example, in 1991 (Pelcovitz, 2013) [2] the National Institute of Child Health and Development initiated a comprehensive longitudinal study in the United States on the relationship between maternal employment, the experience of child care and various conditions in children. The results show that children whose mothers work part-time before their one-year-olds have fewer annoying behavior problems than children of full-time mothers before their child's first birthday. This increased risk of behavioral difficulty is seen at age three. Cognitively it was found that children of full-time working mothers in their first year of life received low children's cognitive scores simply compared to children of part-time working mothers. Mothers who work full-time tend to have symptoms of depression. Other studies have shown that working mothers and away from their children are regularly less sensitive to their child's cues and leads and thus weaken the mother-child relationship (Galinsky, 1999; Hoffman \& Youngblade, 1999) [3] [4].

Conclusions about the negative impact on the research of mothers working abroad certainly cannot be generalized, specifically for example used for conditions in Indonesia. There are many possible variables. For example, the involvement of husbands, siblings, grandmothers or grandparents, socioeconomic status, education and even marital status and occupations of the mother. This article will discuss the mother working in the factory as well as its impact on parenting patterns.

The forms of parenting are very influential and closely related to the personality of the child after he becomes an adult. The character and personality of the individual are the accumulation of a long process and formation from the time he was a child. Because the mother's natural and emotional person is very close to her children, then the mother is the individual 
who plays the most role in the formation of the child since birth.

\section{LITERATURE REVIEW}

\section{A. Working Mother}

Working mothers refer to mothers of children employed on part-time or full-time salaries (Hoffman \& Youngblade, 1999) [4]. A working mother is a mother performing an activity to earn a living (Purwadarminta, 2003; Parlele, 2016) [5]. There are various sectors that are the work of a mother, one of which is in the factory sector. When viewed from the motive of working according to Rachman (2010: Mahfudhah, ----) [6] [17], then every working mother will have different motives such as:

1. Because of the economic necessity, to improve the family economy.

This happens because of the family economy that demands the mother to work. For example, if the family's economic life is less, the husband's income is less to meet the daily needs of the family so that the mother must work.

2. Because want to have or build a job

This happens as a form of self-actualization of the mother, for example, if the mother of a scholar would prefer to work to build a job.

3. Due to the awareness that development requires manpower both men and women labor.

This happens because the mother has a high national awareness that her country needs manpower for the smooth of development.

Today, working mothers are the result of a shift in cultural values. Formerly a mother focused more on the affairs of children and household affairs, but now the mother has a dual role both as the caregiver, child educator as well as an additional breadwinner to support the family.

\section{B. Parenting Style}

Parenting style is defined as the treatment of parents to meet the needs, provide protection, and educate children in everyday life (Sarwono, 2010) [7]. Pattern means order, model, shape, ordinance, style of doing things. While caring ways, foster interaction and communication attentively so that children grow and develop into a mature person and able to create a harmonious condition in the family and community. So that parenting style is a way or model of someone in guiding and educating other people who are different in their care environment and able to create a harmonious condition in the family and community In this discussion someone is interpreted as parents, while others are defined as children. Parenting style is defined as a parentingchild interaction with certain parenting skills (Darling \& Steinberg, 1993) [8].

Parenting style is the way or model of someone in guiding and educating other people who are different in their care environment and able to create a harmonious condition in the family and community environment. Baumrind (1967) [9] states that the pattern of upbringing is formed from the existence of two dimensions of parenting, namely acceptance/responsiveness; describes how parents respond to their children, relating to the warmth and support of parents. Refers to several aspects, namely; the extent to which parents are supportive and sensitive to their children's needs, are sensitive to children's emotions, cares about the well-being of children, willing to spend time and do activities together, and are willing to give love and compliments when their children perform or meet their expectations. Can accept the child's condition, loving responsive parents and often smile praise, and encourage their children. They also let their children know when they are misbehaving or doing wrong. Accepting and responsive parents often quickly criticize, degrade, punish, or neglect their children and rarely communicate to children that they are loved and respected.

The second is the demandingness/control dimension that describes how the standard set by the parent for the child, related to the behavior control of the parent. Referring to several aspects namely; Restrictions demands that children meet rules, attitudes, behaviors and social responsibilities by the standards that apply to the wishes of parents, the presence of strict attitudes related to the attitude of parents who are strict and assertive in keeping the children meet their rules and demands.

Based on the results of research Baumrind (1967) [9] said three types of parenting style are: authoritarian, authoritative and permissive. Then Maccoby \& Martin (Wing Lam, 2016) [10] added another kind of parenting pattern with uninvolved/neglectful parenting. The following can be illustrated the parenting style. 


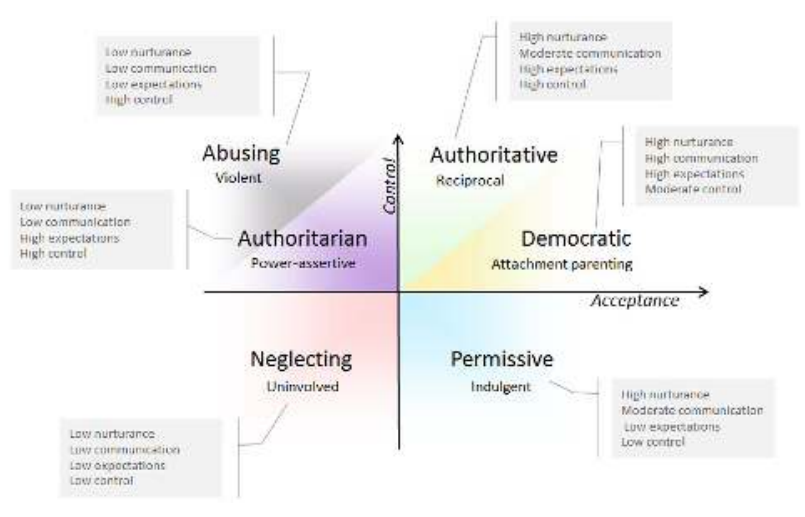

Picture 1.

Baumrind Parenting Style (parentastic.org)

\section{Type of Parenting Style}

There are several styles of parenting. A prominent parenting expert, Baumrind (1967, Winsler, Madigan, \& Aquilino, 2005) [11] states that there are four types or forms of parenting styles such as:

1. Authoritarian Parenting style is a parenting style that expects things that are unrealistic and inappropriate for the child. Parents with this pattern do not show responsiveness to the needs of the child.

2. Authoritative Parenting style is a parenting style that shows a high expectation and responsive in looking at the needs and abilities of children.

3. Permissive parenting style / Indulgent is a parenting style that shows a high responsiveness but is not accompanied by expectations and application of rules to children.

4. Uninvolved Parenting style is a parenting style that shows a low level of responsive and control implementation so that interaction with children is very limited.

\section{Factors Influencing Parenting Style}

According to Hurlock (1997) [12], several factors affect parental parenting, namely:

1. Socioeconomic level

The elderly who came from the middle social-economic level were more warmhearted than the elderly from low socioeconomics.

2. Education Level

Higher parental education backgrounds in the practice of care are seen more frequently reading articles or following the development of knowledge about child development. In nurturing their children, they become better prepared for having a broader understanding, whereas parents with limited educational backgrounds have limited awareness and understanding of the needs and development of the child to show less understanding and tend to treat their children with a strict and authoritarian.

3. Personality.

The personality of the parents can affect the use of parenting. Conservative parents tend to treat their children with strictness and authoritarianism.

4. Number of children

Parents who have children only 2-3 people (small families) tend to be more intensive care, where the interaction between parents and children more emphasis on personal development and cooperation among family members more attention. While parents who have children numbering more than five people (large families) are very less have the opportunity to control intensively between parents and children because parents automatically reduced attention to each child.

While Santrock (1995) [13] mentions several factors affect the parenting style, among others:

1. Decreased previous parenting methods. Parents apply parenting style to children based on previous parenting style.

2. Cultural changes, namely regarding values, norms, and customs between the past and present.

The above opinion is also supported by Mindel (Walker, 1992 :) [14] which states that there are several factors that influence the formation of parenting patterns in the family, including 1) the local culture, in this case, includes all the rules, norms, customs and culture that developed in Inside; 2) The ideology that develops in the parents because parents who have certain beliefs and ideologies tend to lower to their children in the hope that later values and ideologies can be embedded and developed by children in the future; 3) geographical location and ethical norm.

Soekanto (2004) [15] outlined that "there are two factors that influence in the care of a person that is external factors and internal factors." External factors are the social environment and the physical environment and the working environment of the parents, while the internal factor is the model of parenting style that has been obtained previously. In 
further discussion of the factors that contribute to parenting style are:

The social and physical environment in which the family lives.

1. The pattern of family care is influenced by the place where the family lives. If a family lives in an environment with low educated authority and low levels of manners, then the child can easily also be affected.

2. Model parenting style gained by parents before

Most of the parents apply parenting style to children based on the pattern of parenting they get before. This is reinforced if they see the pattern of upbringing that they once got a success.

3. Parent work environment

Parents who are too busy to work tend to give up their child care to the people closest or even to the baby sitter. Therefore, the pattern of parenting gained by the child is also appropriate with the person who cares for the child.

From the description above can be seen that the factors that affect parenting style is the existence of things that are internal (originated in the self) and is external (coming from outside). It determines the upbringing pattern of the children to achieve the goals to conform to the prevailing norms.

\section{Methodology}

This paper is a summary of research prepared using a qualitative approach with case study method. The respondent of the study is the working mother of one factory in Bandung Regency which has 2 - 6 year old child. Exposed 20 respondents who became the subject of research. The data was collected in March 2017. The data collection tool used Parenting Style and Dimension Questionnaire (PSDQ) instrument Baumrind.

\section{RESULT}

Table 1

Overview Parenting Working Mothers in Factory

\begin{tabular}{|l|l|l|}
\hline Parenting Style & F & $\%$ \\
\hline Authoritarian Parenting Style & 6 & 30 \\
\hline Authoritative Parenting Style & 5 & 25 \\
\hline Neglectful Parenting Style & 3 & 15 \\
\hline Indulgent Parenting Style & 6 & 30 \\
\hline$\sum$ & 20 & 100 \\
\hline
\end{tabular}

Based on table 1 then it can be seen that the mother parenting style that works in the most dominant factory that is Authoritarian Parenting Style and Indulgent Parenting Style. Authoritarian parenting is parenting that expects things that are unrealistic and inappropriate for the child. Parents with this pattern do not show responsiveness to the needs of children (Wing Lam, 2016) [10]. Parents with Authoritarian Parenting Style, tend to limit and punish, urging children to follow the word mother, to respect for the elderly, and to have a high degree of rigidity, and to have little communication intensity. Baumrind (1967) [9] states that educated children have an authoritarian attitude that is less socially competent, poor communication skills, and fear of social comparisons. With such an authoritarian style the child will tend to rebel. While Indulgent Parenting Style is a parenting pattern that shows a high responsiveness but not accompanied by hope and application of rules to children (Wing Lam, 2016) [10]. In this parenting style, mothers tend to comply with all children's wishes and very rarely limit the behavior of children. Children with this parenting pattern are usually children who are difficult to control their behavior because they are used to being pampered.

Based on supporting data, it was revealed that the reason for the mother to treat the child by indulgent (on Indulgent Parenting Style) because the mother realized the lack of time to interact with children as a result of busy work. Mothers feel the need to devote love to children by following the things that children want. While in the mother with Authoritarian Parenting Style reasoned that they do not want their children to have a less fortunate fate like their mother. So the mother feels the need to arrange and follow the words of the mother for the future of children more bright and more fortunate.

There are interesting findings where most of the mothers who exhibit authoritarian, neglectful and indulgent parenting style have high school education background. This is in line with the opinion Maccoby (1980) [16] said that the educational background of parents could indeed affect the parental mindset both formal and non-formal which affects the aspirations or expectations of parents to their children.

Table 2.

Motivation of Mother's Working at Factory

\begin{tabular}{|l|l|l|}
\hline Motivation & F & $\%$ \\
\hline Economic & 14 & 70 \\
\hline Fostering work & 4 & 20 \\
\hline Self Actualization & 2 & 10 \\
\hline$\sum$ & 20 & 100 \\
\hline
\end{tabular}

Based on table 2 it can be seen that most or $70 \%$ of mothers who work in the factory due to economic motives. The inadequate family situation forces the mother to work. Nevertheless, from the interviews, it is known that mothers still feel the importance of education for children. Therefore, from 
20 respondents who were interviewed, as many as 15 mothers or $75 \%$ of mothers send their children to the nearest PAUD. The rest as many as 5 mothers have not sent their children related to age. When mothers was asked about how to plant religious values in children. There are still many mothers who have not applied religious values in their daily life with children. There are only 6 mothers who have embedded religious values in daily life such as taking children to pray, praying on time, reading prayers before eating, reading prayers while sleeping, and teaching greetings on the go.

The twenty mothers interviewed saw the importance of religious cultivation in educating children. Only mothers who have not applied it do not have sufficient knowledge about it so that mothers assume that what is taught in PAUD school is enough for children.

Islamic Parenting Style: Theoretical and Practical Solutions

Every Muslim must believe and practice the teachings that have been demonstrated through the fundamental normative sources, namely Al-Quran and Al-Hadith. Every Muslim parent is required to make both sources a foundation and foundation in doing various activities, not least in guiding and educating children. To be able to run the process of guidance and education properly and correctly, every parent must have a correct view and understanding of the child with all its aspects.

The Qur'an has explained the position of the child to the parents, among them: the child is a trustee, of the next generation, the right deeds of charity, and as the heart for the heart of his parents. As a trustee, the child is entrusted by Allah to every parent to be guided and educated by the purpose of its creation, that is to be a servant of God who always obeys His provisions and become the Khalifah of Allah on earth who always create goodness and welfare. Therefore, guiding and educating children is part of the obligation of every parent who will be held accountable so required to be done with full responsibility. The child is the next generation who will continue and accept the life-responsibility estimate requires a guidance and educational pattern that leads him to be strong and resilient to all life's challenges and keep him from the characteristics of the hell-hood. The task of parents in guiding and educating their children will also be a field and investment of his charity. If the parent succeeds in carrying out his duties properly and appropriately, then it will be a field or investment of good deeds, otherwise, if it fails then the bad consequences will be received. The position of the child for his / her parents can be the jewel of the heart that is the source of his comfort and happiness. Therefore, every parent should guide and educate his children with great compassion and say, as the nature of God's womb and womb. At the same time, every parent should be vigilant because the pride of children can make the parents slip off the path of Allah SWT.

Based on the position of the child as described above Al-Quran, then there are at least three main obligations that must be carried out every parent in guiding and educating their children, namely: introducing and instilling the basic relationship with Allah SWT (hablu minallah); Introducing and reinforcing the basis of harmonious relations with others and the surrounding environment (hablu minannas wa hablu minal kaun); And instilling a solid foundation in facing the challenges of the times. Harmonization of relationship with Allah SWT can be built by giving an understanding of human existence in relation to macrocosm and Khaliq. The Qur'an asserts that the main purpose of human creation is to be a servant (Surat al-Dzariyat / 51: 56) as well as the khalifah of Allah (Surah Al-Baqarah / 2: 30). While the harmonization of relationships with others in the environment can be planted by giving an understanding of the human position as a social creature and at the same time from nature. With these two harmonizations, each individual is delivered to become a Muslim that capable of showing the piety of ritual (individual) as well as social piety. Children are the hope of the future so that the obligation of every parent to deliver them to be strong and tough people face all the challenges of the times by guiding and educating them futuristic.

In addition to the above explanation, the Qur'an has provided a strong foundation in establishing the principles of guiding and parenting, namely the principle of reminding, truth, patience and compassion (Muhammad Abduh Tausikal, 2009). Reminding is the first and foremost principle based on the teachings of the Qur'an as stated in the following verse.

\footnotetext{
Meaning:

"Then face your face straight to the religion of Allah; (Abide) the nature of Allah who created the man according to his nature. There is no change in the nature of God. (That is) a righteous religion; But most humans do not know. " (Surat ar-Rum / 30: 30)
}

Based on the above verse Allah informs that every individual (child) is created by bringing fithrah to be preserved. Continuing the verse also reminds that most people do not know it so that they cannot maintain and develop it. Therefore the obligation of parents to remind him through guidance and education. Reminding means not forcing, not printing, but guiding finding fithrah. Essence to remind is to build a commitment to children to always hold fast to the values of universal truth. The truth value affirmed by the Qur'an is that the life of the world with all its jewelry is a mirage-inspired test that can awaken lust and neglect humanity as the 
primary enemy (Surah Ali Imran / 3: 14). This is where the task of parents to remind the path of universal truth according to the guidance of the Most True God Almighty.

The principle of truth must be instilled precisely and accurately. The most important thing in instilling the value of truth is instilling the belief that Al-Quran and Al-Hadith are the source of truth of every Muslim. The ultimate truth can only be achieved with adequate knowledge. Therefore the first and foremost thing in instilling the truth is to provide children with knowledge. For this purpose every parent must refer to QS. Al-Nahl / 16: 78).

\section{Meaning:}

"And Allah took you out of the belly of your mother in the state of not knowing anything, and He gave you hearing, sight, and heart, that may be grateful."

(Surat al-Nahl / 16: 78)

Devices that Allah has given to each in the form of hearing, sight, and heart. The hearing is an instrument for capturing words; then every parent should keep and can choose words because those words will affect the child's soul. Vision is an instrument that will capture all the behaviors and events that occur. A good example is the key to immersing the love of truth. The heart is the center of consciousness and reasoning power and the passion of love. Every parent is required to guide and educate with a sincere heart to give birth to a sincere individual and filled with love as well.

Patience is an easy word to say but not easy to live. Patience is an indication of one's greatness. Parents should guide and educate children with patience as well as a goal to be implanted and always reminded to his children. Patience must be placed as one of the strengths of one's faith. Thus it is fitting that one of the characteristics of the one who will not lose is the one who counsels with truth and patience. Only with the patience of parents will be able to avoid the attitude of ignorance and do not care about his children.

\section{CONCLUSION}

The affection shown by parents in guiding and educating their children is their sincerity and solemnity in carrying out the mandate. Children are the trust and entrustment of Allah SWT to every parent who should be nurtured, developed, reminded with patience. Patience that plenary in turn shows true parental love to his child.

This reasoning and awareness based on the teachings of Islam are what every parent should have, including mothers as factory workers. Taking note of the above data, it is difficult to express the direct link between the level of education and the work motive with the pattern of care shown by the families of factory workers' mothers. Thus the researchers think the basic concept of Islam about parenting will be used as a solution for the improvement of care pattern in the family of factory workers' mothers in addition to further practical and technical programs.

\section{REFERENCES}

[1] Ansyari, Syahrul., \& Ade Alfath. (2015). KPAI: Kekerasan terhadap Anak Meningkat Tajam. Tersedia secara online di http://nasional.news.viva.co.id/news/read/655240-kpai-kekerasan-terhadap-anak-meningkat-tajam. diakses tanggal 20 Desember 2015.

[2] Pelcovitz, David. (2013). The Impact of Working Mother on Child Development. Tersedia di : https://www.ou.org/life/parenting/impact-workingmothers-child-development-empirical-research-davidpelcovitz/ diakses tanggal 20 April 2017.

[3] Galinsky, E. (1999). Ask the children: What America's children really think about working parents. New York: William Morrow.

[4] Hoffman, L.N., \& Youngblade,L.M. (1999). Mothers at work : Effects on children's well-being. Cambridge, New York : Cambridge University Press.

[5] Parlele, Johanna. (2016). Gambaran Pengasuhan Anak Ditinjau dari Tingkat Pendidikan \& Pekerjaan Ibu. Universitas Kristen Satya Wacana.

[6] Mahfudhah, Desi. (---). Hubungan Pengetahuan, Sikap Dan Pekerjaan Ibu Terhadap Perilaku Hidup Bersih Dan Sehat Pada Tatanan Rumah Tangga Di Desa Reukih Dayah Kecamatan Indrapuri Kabupaten Aceh Besar. Jurnal UII. Tersedia online http://www.ejournal.uui.ac.id/jurnal/DESI_MAHFUD HAH-wpk-jurnal desi.pdf.

[7] Sarwono, S. W. (2010). Psikologi Remaja Edisi Revisi. Jakarta: Rajawali Pers.

[8] Darling, N., \& Steinberg, L. (1993). Parenting style as context: An integrative model. Psychological bulletin, 113 (3), 487-496.

[9] Baumrind, D. (1967). Child Care Practices Anteceding Three Patterns of Preschool Behavior. Genetic Psychology Monographs Journal, Vol 75(1), p. 43-88.

[10] Wing Lam, Tsui. (2016). Case study on working mother's parenting style and the effect on child's social competence. The Hong Kong Institute of Education.

[11] Winsler, A., Madigan, A. L., \& Aquilino, S. A. (2005). Correspondence between maternal and parental parenting styles in early childhood. Early Childhood Research Quarterly Journal, 20, 1-12.

[12] Hurlock, Elizabeth B. (1997). Psikologi Perkembangan Suatu Pendekatan Sepanjang Masa. Edisi kelima. Jakarta: Erlangga.

[13] Santrock, John W. (1995). Life Span Development. Jakarta: Erlangga.

[14] Walker, C. E. (1992). The Handbook of Clinical Child Psychology. Canada: A. Wiley-Inter Science.

[15] Soekanto, S. (2004). Sosiologi Keluarga. Jakarta: Rineka Cipta

[16] Maccoby, E. (1980) . Social development-psychological growth and the parent-child relationship. New York: Harcourt Brace Jovanovich. Dapat di akses di http://repository.uksw.edu/bitstream/123456789/10215/ 2/T1_802013709_Full\%20text.pdf

[17] Rachman, Eileen \& Sylvitri. (2010). Motivasi Sumber Energi Saat Bekerja. Dapat di akses di http:// famale.kompas.com/read 